\title{
Latex Allergy in a Patient with Kabuki Syndrome. Case Report
}

\author{
Vera Coelho Teixeira, TSA ${ }^{1}$, Maria Amélia Neves ${ }^{2}$, Roberto Almeida de Castro ${ }^{3}$
}

Summary: Teixeira VC, Neves MA, Castro RA - Latex Allergy in a Patient with Kabuki Syndrome. Case Report.

Background and objectives: The knowledge of anesthesiologists of specific aspects of patients with rare syndromes is a growing need since those patients are increasingly taken to the operating room. The objective of this report was to describe a case of latex allergy in a patient with Kabuki Syndrome, whose aspects have not been completely explained, alerting anesthesiologists for the possibility of this association.

Case report: This is an 11 years old patient with the diagnosis of Kabuki syndrome, admitted for removal of soft tissue lesions. She had a history of allergic reactions after small surgeries. Since she needed to undergo another procedure, after the pre-anesthetic evaluation the patient was referred to an allergist who confirmed, after skin tests, that the patient had latex allergy. She was taken to the operating room for removal of those lesions under general anesthesia. All precautions were taken to avoid new clinical manifestations. Intercurrences were not observed during the procedure and the patient was discharged on the same day without any complications, which reinforced the diagnosis.

Conclusions: Kabuki syndrome seems to have a relatively benign course. However, it has many aspects that remain to be cleared and, therefore, the possibility of its association with other condition that might be important for the anesthesiologist exists. The objective of this report was to alert for the risk of its association with latex allergy. For such, during the pre-anesthetic evaluation, a good anamnesis with analysis of predisposing factors other than the syndrome itself should be stimulated.

Keywords: ANESTHESIA, General; EVALUATION: pre-anesthetics; DISEASES, Genetic: Kabuki syndrome; COMPLICATIONS: Iatex hypersensitivity.

[Rev Bras Anestesiol 2010;60(5): 544-550] @Elsevier Editora Ltda.

\section{INTRODUCTION}

Kabuki syndrome (KS) is a rare disorder with very few data in the literature and, therefore, its association with the lack of knowledge of all of its aspects. Initially described by two Japanese groups in 1981, Nikawa et al. ${ }^{1}$ and Kuroki et al. 2 , it was thought to be more common in that population. However, since then with the dissemination of the information it has been reported in the most different countries and ethnic groups, including Brazil, Europe, Philippines, Vietnam, India, and Mexico among others, confirming that the pathology is not restricted to specific populational groups.

The term Kabuki was used by Nikawa et al. ${ }^{1}$ since typical facial changes resemble the makeup of actors of this traditional Japanese theater. In that population, the estimated prevalence was $1 / 32,000{ }^{3}$ and it is believed that this number will reflect more appropriately the world reality, considering that greater knowledge of the disease by the medical community will increase the number of cases diagnosed ${ }^{4}$.

Received from the Hospital Felício Rocho, Belo Horizonte - Minas Gerais.

1. Co-responsible for the CET of the Hospital Felício Rocho, specialist in Internal Medicine and Intensive Care, Anesthesiologist of the Hospital Felício Rocho

2. Anesthesiologist of the Hospital Felício Rocho

3. R3 of the CET of the Hospital Felício Rocho

Submitted on January 20, 2010.

Approved on May 24, 2010.

Correspondence to:

Dra. Vera Coelho Teixeira

Alameda Serra da Mantiqueira 478

Vila del Rey

34000-000 - Nova Lima, MG, Brazil

E-mail: verateixeira@yahoo.com.br
Currently, a consensus regarding diagnostic criteria or even a genetic test clinically available that will lead to the definitive diagnosis of the disease does not exist. The work of Nikawa of $1988^{3}$, who evaluated the common characteristics of 62 patients with this syndrome, defined five main clinical manifestations. The first one, and the most common (seen in $100 \%$ of the patients) is the typical facies characterized by eversion of the inferior and lateral portion of the inferior lids, arched eyebrows with the lateral portion with very few hair, flattened nose tip, and prominent ears. Other manifestations include skeletal changes, low stature, and dermatoglyphic changes.

Some studies have reported that race has very little influence on the phenotypical manifestation of the disease especially those in the face, which makes it an important characteristic. Kawame et al. ${ }^{5}$ have suggested as minimal diagnostic criteria the presence of long palpebral fissures with eversion of the lateral portion of the inferior eyelids, thick arched eyebrows with rarefying hairs laterally, prominent ears, developmental delay, and mental retardation. Although a consensus on the diagnostic criteria does not exist, the diagnosis is clinical and depends on the findings described.

Affected patients can present non-specific changes in organs and systems. It is possible to find cardiac, renal and genitourinary, gastrointestinal, neurologic, respiratory, and immunologic changes. The differential diagnosis of this syndrome includes other rare genetic syndromes and involves less common traces of the disorder. Examples include the syndrome of deletion of 22q11 (DiGeorge syndrome), which aspects such as cleft palate, and cardiac and renal malformations can also be found in patients with Kabuki syndrome. The same line of thought applies to van der Voude syndrome, an autosomal dominant disorder, in which cleft palate and lip, 
and hypotonia are common. Both have specific genetic changes not found in Kabuki syndrome.

The cause of this disorder remains unknown. Several cytogenetic changes have been described, including duplication of $1 p$ [dup(1)(p13.1p22.1)], a hereditary translocation between chromosomes 3 and 10 [t(3;10)(p25;p15)], a hereditary paracentric inversion of the short arm of chromosome 4 [inv(4) (p12pter)], and a partial 6q monosomy with partial 12q trisomy [der(6)t(6;12)(q25.3;q24.31)] among others ${ }^{4}$. However, the most common change is related to chromosome $\mathrm{X}$ and some authors, like Milunsky et al., feel that this duplication could represent a common aspect among the cases.

Kabuki syndrome has been recognized as a genetic syndrome for only a short time. This leads to the conclusion that we have very little to say regarding the natural history of this disorder. Controversies regarding phenotypical manifestations, time of development, and the moment they become more evident generate diagnostic difficulties, which would lead to recording of only the more evident cases. However, since the pathology is not strongly associated to more serious clinical conditions, it is assumed that its evolution is relatively benign, especially in those forms without cardiac changes and infections that patients are exposed to are adequately identified and treated.

Due to what has been exposed, especially concerning the need of spreading more data on this disorder, the objective of the present study was to describe the case of a patient with Kabuki syndrome and latex allergy who underwent a surgical procedure. We also undertook a critical analysis of the diagnosis of allergy and the methods used on its diagnosis. Note that we did not find any cases of similar nature in the literature.

\section{CASE REPORT}

This is a 11 years old female patient weighing $40 \mathrm{~kg}$ with the diagnosis of Kabuki syndrome, typical facies (Figures 1 and 2 - pictures were taken with authorization of her parents) and history of delayed neuropsychomotor development, otitis, and repeated urinary tract infections (UTI) due to vesicoureteral reflux, without involvement of other organs or systems.

She had already undergone two surgeries, during which she developed allergic reactions without definition of the cause and with different clinical manifestations. The first procedure, of short duration, consisted on the removal of a benign tumor in the dorsum with progressive growth when she was 5 years old, under general anesthesia. During induction, she had developed mild bronchospasm and cutaneous rash that did not interfere with the peroperative management. She was intubated without difficulty. In the recovery room after being extubated she required micronebulization with adrenaline (half ampule), dexamethasone (10 mg), and $2 \mathrm{~mL}$ of NS due to hoarseness, which improved. After being transferred to the regular ward, she had three episodes of vomiting, being treated with $0.7 \mathrm{~mL}$ of metoclopramide IV. She was discharged on the following morning without further complaints.

After that, her parents were oriented to take the patient to an allergist with the information of the drugs used in the anesthesia.

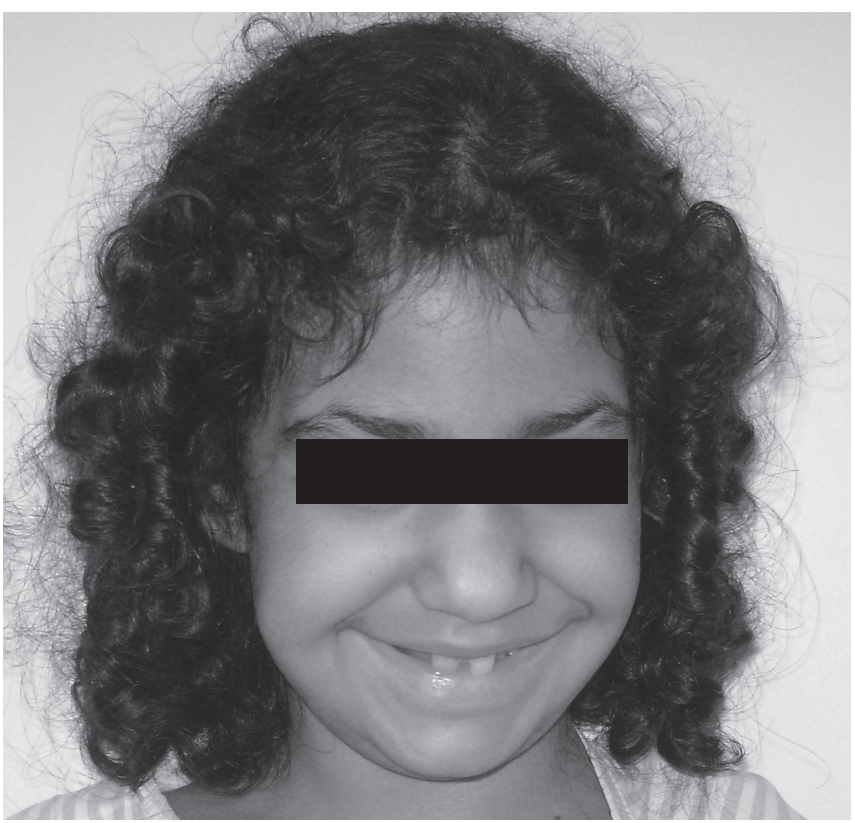

Figure 1. Picture taken after permission from her parents.

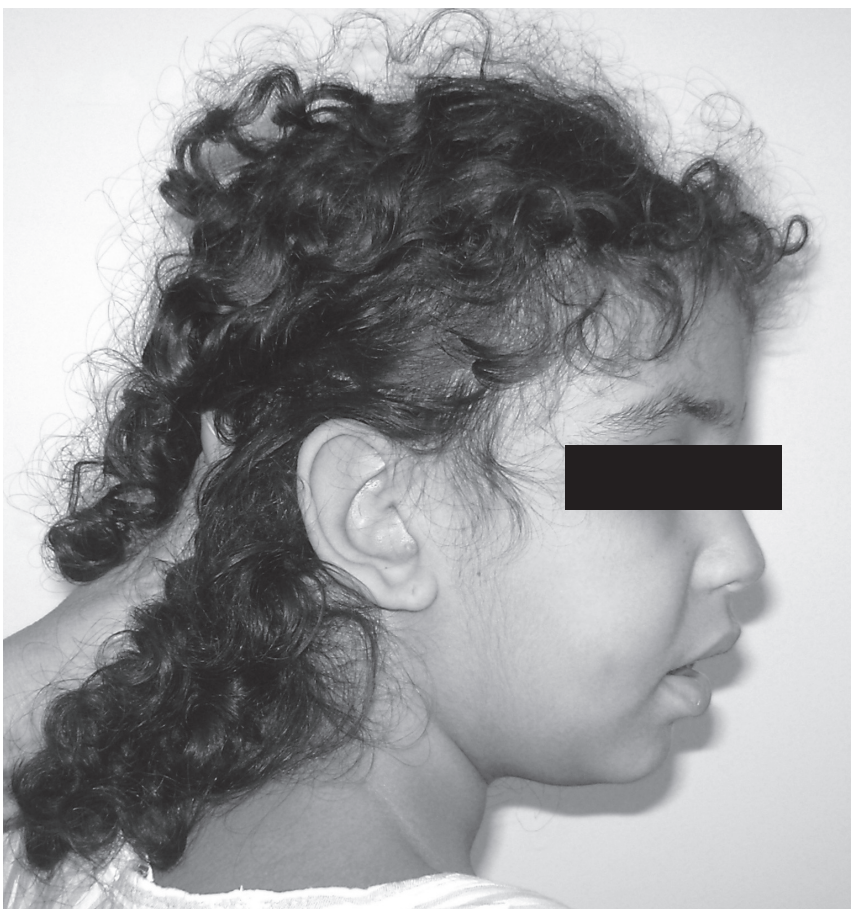

Figure 2. Picture taken after permission from her parents.

After being evaluated, we received a report stating that it would not be possible to identify the causative agent since at that time immunologic tests to detect allergies were not available in Brazil, and provocation testing could place the child at risk.

The second surgery was performed approximately 2 years later for excision of subcutaneous lesions. Once more, the patient underwent general anesthesia and no intercurrences were observed in the anesthetic-surgical procedure. The patient was discharged from the hospital and when she arrived home her parents noticed the development of facial edema and dyspnea. 
They took her to the hospital where she was treated for a probable allergic reaction, characterized by angioedema.

In view of the new indication for removal of skin and subcutaneous lesions, the patient was referred for pre-anesthetic evaluation, and the anesthesiologist once more (6 years later) referred her to an allergist giving her mother a list of the medications used in previous procedures for testing.

During the evaluation, cutaneous testing with substances of the resin-epoxy group was positive. Among the substances the patient should avoid contact with were those containing latex. Therefore, the patient was once more taken to the operating room where care was taken to avoid contact with material containing this substance according to the hospital protocol. She received oral midazolam approximately 30 minutes before being taken to the operating room with a latex-free environment. Anesthesia was induced with sevoflurane. Afterwards, peripheral venous access with a 20G catheter was established followed by the administration of $10 \mu \mathrm{g}$ of sufentanil for orotracheal intubation, which was performed with a number $6 \mathrm{ET}$ tube with balloon.

The patient was monitored with electrocardiogram, pulse oximetry, non-invasive blood pressure, and capnography. Anesthesia maintenance was accomplished with sevoflurane at approximately $1 \mathrm{MAC}$. She also received $1 \mathrm{~g}$ of dypirone. Three lesions were removed under general anesthesia, which lasted 40 minutes without intercurrences. She was extubated in the post-anesthetic recovery room without intercurrences. Her room was also latex-free. On the same day, she was discharged home and she did not present any symptoms.

\section{DISCUSSION}

Anesthesia of patients with rare syndromes always generates anxiety. In this case, the report of latex allergy made us take additional care. The patient had typical facies of the syndrome and other aspects common to this syndrome, such as prominent and arched ears, arched eyebrows with paucity of hair in the lateral portion, and clubbing of her fingers. She had mild psychomotor delay, and she had a history of repetitive infections (otitis and UTI that reinforced the diagnosis since this type of patient can present immunologic changes that predisposes her to infections.

Cases of latex allergy have become increasingly more common ${ }^{7}$. The introduction of universal precaution measures, which includes the use of latex-containing gloves, represented a great contribution for the development of this allergy not only in patients but also in health care professionals. Its spectrum of manifestations is extremely wide ranging from a simple rash to anaphylactic shock.

The diagnosis is based on a detailed anamnesis in specific questionnaires and by using in vivo and in vitro laboratorial testing ${ }^{8,9}$. In this case, the patient had a history that raised the suspicion of latex allergy. She had already undergone two procedures in which care to avoid contact with latex-containing products were not taken, and she presented symptoms typical of allergic reactions.

Those types of allergic reactions presuppose, necessarily, prior contact with the suspected substance and, although there was nothing concrete in the history of the patient before the first reaction, she had probably been in contact with latexcontaining substances without any problems. This condition has been foreseen and it is described as sensitization. This process does not trigger a clinically manifest picture, being defined by the presence of immunoglobulin-type antibodies ( $\operatorname{lgE})$ against latex. Allergy to this substance is seen in any immune-mediated reaction associated with clinical symptoms, which include types 1 and 4 hypersensitivity reactions ${ }^{10}$.

It should be emphasized that one of the latex-triggered manifestations is contact dermatitis that by definition is not a genuine allergic reaction since an immune mechanism is not involved. It is the most common. Type 4 hypersensitivity reactions are characteristically deferred, they do not trigger systemic involvement, and are responsible for dermatologic changes. Type 1 or immediate reactions are more worrisome, since they can present as severe reactions. The patient should have been previously sensitized to lgE-specific substances produced during a prior contact that are bound to the membrane of mastocytes and basophils. Upon a new contact with the antigen, its interaction with membrane-bound immunoglobulins triggers the degranulation process of those cells with the release of inflammatory mediators (histamine and leukotrienes, among others). The cases of latex allergic reactions in patients undergoing surgical procedures usually develop 30-60 minutes after induction, which might help differentiate drug reactions that usually develop only a few minutes after exposure ${ }^{8,9}$.

The patient had a history of two previous reactions in different procedures. The first developed shortly after induction, and manifested with respiratory symptoms and rash that persisted during the observation period and improved only after treatment. The behavior of this reaction is compatible with type 1 . In the second procedure the patient developed a new picture with traces of allergic reaction, once more with characteristics of type 1 reaction, several hours after the surgery, which makes us believe on re-exposure to the responsible antigen that is feasible with latex and less probable in the case of drugs.

With this history, before the last procedure reported, we decided to refer her to be evaluated by a specialist. The diagnosis was made after cutaneous testing, which showed positivity for substances of the resin-epoxy group. Usually, those tests are used to diagnose type 4 reactions, while type 1 reactions are investigated by serology, not common among us. Due to the diagnosis, every care was taken to minimize the contact of the patient with the substance, a strategy which was proven effective and it reinforced the diagnostic suspicion. The protocol of this hospital, implemented a few years ago, foresees precaution with contact with latex during the time of hospitalization. When scheduling a procedure, care is taken that all environments prepared for the patient are latex-free.

In conclusion, Kabuki syndrome deserves better understanding. Every day more cases are described increasing our understanding on the subject. The case reported here reinforces this tendency and awakens the anesthesiologist for the possibility of the association of Kabuki syndrome with allergies, as well as allowed the discussion of the aspects related to the management of a patient with latex allergy. 
anomalies associated with postnataldwarfism and mental retardation. J Pediatr, 1981;99:570-573.

03. Niikawa N, Kuroki $\mathrm{Y}$, Kajii T et al. - Kabuki make-up (Niikawa-Kuroki) syndrome: a study of 62 patients. Am J Med Genet, 1988; 31: 565-589.

04. Adam MP, Hudgins L - Kabuki syndrome: a review. Clin Genet, 2004; 67:209-219.

05. Kawame H, Hannibal C, Hudgins L et al. - Phenotypic spectrum and management issues in Kabuki syndrome. J Pediatr, 1999;134: 480-485.

06. Milunsky JM, Huang JM. - Unmasking Kabuki syndrome: chromosome 8p22-8p23.1 duplication revealed by comparative genomic hybridization and BAC-FISH. Clin Genet, 2003;64:509-516.

07. Lebenbom-Mansour M, Oesterle JR, Ownby DR et al. - The incidence of latex sensitivity in ambulatory surgical patients: a correlation of historical factors with positive serum immunoglobin E levels. Anesth Analg, 1997;85:44-49.

08. Allarcon JB, Malito M, Linde $\mathrm{H}$ - et al Alergia ao látex. Rev. Bras. Anestesiol, 2003;53:89-96.

09. Hepner DL, Castells MC - Latex allergy: an update. Anesth Analg, 2003;96:1219-1229.

10. Sussman G, Talo S, Dolovich J - The spectrum of IgE-mediated responses to latex. JAMA, 1991;265:2844-2847.

Resumen: Teixeira VC, Neves MA, Castro RA - Alergia al Látex en Paciente con Síndrome de Kabuki: Relato de Caso.

Justificativa y objetivos: El conocimiento del profesional de Anestesiología sobre los aspectos específicos de pacientes portadores de síndromes raros, es una necesidad que ha venido creciendo, pues cada vez más, esos pacientes son derivados a los quirófanos. Nuestro objetivo es describir un caso de alergia al látex que ocurrió en uno de esos pacientes con diagnóstico del Síndrome de Kabuki, y cuyos aspectos todavía no fueron completamente aclarados, alertando a los anestesiólogos en cuanto a la posibilidad de esa asociación.

Relato del Caso: Paciente de 11 años, con diagnóstico de Síndrome de Kabuki, que fue admitida para exéresis de lesiones de las partes blandas. Presentaba un historial de reacciones alérgicas previas posteriores a los procedimientos quirúrgicos de pequeño porte. Con la necesidad de realizar un nuevo procedimiento, y después de la evaluación preanestésica, la paciente fue derivada a un alergista que la sometió a pruebas cutáneas las cuales confirmaron la hipótesis de alergia al látex. Una vez más fue enviada al quirófano para exéresis de las lesiones bajo anestesia general. Fueron tomadas todas las precauciones con el objetivo de evitar nuevas manifestaciones clínicas. El procedimiento transcurrió sin intercurrencias y la paciente recibió alta el mismo día, sin que presentase ningún tipo de complicación, lo que reforzó mucho más el diagnóstico.

Conclusiones: El Síndrome de Kabuki parece tener un curso relativamente benigno en su historial natural. Sin embargo, existen muchos aspectos que todavía necesitan ser aclarados y por lo tanto, no descartamos la posibilidad de la asociación de esa patología con otras condiciones que son del interés del anestesiólogo. Esa descripción tiene el objetivo de alertar sobre el riesgo de la asociación de ese síndrome con la alergia al látex. Para tanto, debemos incentivar la evaluación preanestésica de esos pacientes, la realización de una anamnesis correcta y el análisis de otros factores predisponentes que no sean solo el síndrome por sí mismo. 